\title{
RUMAH KEBERSAMAAN ANTARA HEWAN DAN MANUSIA
}

\author{
Benedikta Jennifer (Christanto ${ }^{1)}$, Franky Liauw ${ }^{21}$ \\ 1) Program Studi S1 Arsitektur, Fakultas Teknik, Universitas Tarumanagara, jennifer.christanto@gmail.com \\ 2)Program Studi S1 Arsitektur, Fakultas Teknik, Universitas Tarumanagara, frankyl@ft.untar.ac.id
}

\begin{abstract}
Abstrak
Manusia merupakan mahkhluk sosial yang saling membutuhkan satu sama lainnya. Manusia sebagai mahkhluk sosial tidak dapat hidup sendiri dan membutuhkan mahkhluk hidup lainnya untuk bertahan hidup. Kota ditandai sebagai tempat dimana masyarakat tinggal dan bekerja serta merupakan pusat perekonomian. Masyarakat kota yang heterogen dan mayoritas penduduknya bekerja non-agraris menyebabkan masyarakat bersifat individualis. Masyarakat mulai melupakan arti sosialisasi yang sesungguhnya dan mulai membangun dinding antara satu dengan yang lainnya. Penelitian ini bertujuan untuk mengurangi tingkat individualis dalam masyarakat kota melalui peran ruang arsitektur serta media hewan peliharaan baik anjing, kucing maupun kelinci. Metode dari penelitian ini, antara lain: pertama, melakukan studi literatur, survei dan melakukan observasi terhadap lokasi dan lingkungan sekitar tapak dan kawasan. Kedua mempelajari kebutuhan dari masyarakat sekitar dan alasan masyarakat menjadi individualis. Ketiga menyusun program yang sesuai dengan kebutuhan masyarakat dengan pendataan aktivitas sehingga diharapkan tujuan dari proyek akan tercapai. Melalui observasi, eksperimen serta berlandaskan dari preseden, diharapkan dapat memperoleh kriteria rancangan arsitektur yang sesuai dengan kebutuhan masyarakat sekitar, dengan tujuan utama untuk menyatukan dan menyetarakan masyarakat sekitar sehingga memudarkan rasa individualis dengan cara berinteraksi baik dengan media berupa hewan peliharaan maupun hobi atau kegemaran yang sama.
\end{abstract}

Kata kunci: arsitektur; hewan perliharaan; individualis; kesetaraan; persamaan

\begin{abstract}
People are social beings who need each other. People as social beings cannot live alone and need other living beings to survive. The city is characterized as a place where people live and work and are the center of the economy. Heterogeneous cities and majority of non-agrarian communities cause the community to be individualist. People begin to forget about the true socialization meaning and start building walls with each other. This research aims to reduce the level of individualism in the city community through the role of architectural space as well as pet media for dogs, cats and rabbits. The methods of this study include: first, conducting literary studies, surveying and observing the location and environment surrounding the site and region; The second learns the needs of the surrounding community and the reason society becomes individualist; All three programs that suit the needs of the community with the activity collection so that the objective of the project will be achieved. Through observation, experimentation and based on precedent, it is hoped that we can obtain the criteria of architectural design to suit the needs of the surrounding community, with the main objective of unifying and interpreting the surrounding community so that Fading the sense of individualism by interacting well with the media of the same pet or hobby or craze.
\end{abstract}

Keywords: architecture; equality; individualism; pets; similarity

\section{PENDAHULUAN}

\section{Manusia sebagai Masyarakat Individualis}

Manusia merupakan mahkhluk sosial yang saling membutuhkan satu sama lainnya. Manusia sebagai mahkhluk sosial tidak dapat hidup sendiri dan membutuhkan mahkhluk hidup lainnya 
untuk bertahan hidup. Manusia mulai berkumpul, membentuk sebuah komunitas dan masyarakat yang besar hingga akhirnya mereka tinggal dalam sebuah lingkup kawasan yang kita sebut sebagai kota.

Kota merupakan pusat permukiman dan kegiatan penduduk. Menurut Rapoport, dalam bukunya yaitu "Tentang Asal-Usul Kebudayaan Permukiman" menyatakan bahwa kota adalah suatu permukiman yang relatif besar, padat, dan permanen, terdiri dari kelompok individuindividu yang heterogen dalam segi sosial. Kota ditandai sebagai tempat dimana masyarakat tinggal dan bekerja serta merupakan pusat perekonomian.

Masyarakat kota yang heterogen dan mayoritas penduduknya bekerja non-agraris menyebabkan masyarakat bersifat individualis. Masyarakat mulai melupakan arti sosialisasi yang sesungguhnya dan mulai membangun dinding antara satu dengan yang lainnya.

Tujuan dari proyek ini adalah:

- Sebagai pemenuhan kebutuhan masyarakat sekitar akan ruang sosial ditengah perkotaan

- Menghadirkan program arsitektur yang mampu membantu masyarakat untuk mengurangi rasa individualis

- Sebagai wadah komunitas bagi masyarakat dengan tujuan yang positif

- Menjadi sebuah tempat yang dapat menyatukan manusia dengan sebuah ketertarikan yang sama

- Menjadi sebuah third place yang dapat mewadahi kegiatan manusia dan hewan peliharaannya

- Menjadi sebuah tempat ramah hewan dan sebagai tempat berkumpulnya komunitaskomunitas masyarakat khususnya komunitas pencinta hewan

Berdasarkan uraian pada latar belakang, maka terdapat beberapa permasalahan yang akan dibahas dalam penulisan ini, yaitu:

- Mengapa masyarakat perkotaan dapat disebut sebagai masyarakat individualis?

- Bagaimana peran arsitektur dalam mengatasi dan membantu masyarakat untuk mengurangi sifat indiviualis?

- Program apa yang cocok dan mampu untuk menyatukan dan mensetarakan masyarakat guna menjadi third place bagi sekitarnya?

- Apa peran hewan peliharaan dalam mengurangi tingkat individualis masyarakat suatu daerah?

\section{KAJIAN LITERATUR}

\section{Third place sebagai Ruang Sosial}

Manusia pada dasarnya adalah binatang sosial; seorang individu yang secara sosial tidak alami dan tidak sengaja berada di bawah perhatian kita atau lebih dari manusia (Aristoteles, 328 SM). Manusia merupakan sebuah spesies primata dari golongan mamalia yang dilengkapi otak berkemampuan tinggi. Manusia dikodratkan untuk hidup bermasyarakat dan berinteraksi satu sama lain, manusia adalah sahabat bagi manusia lainnya, sebuah hal yang membedakan manusia dengan binatang lainnya.

Masyarakat adalah sesuatu di alam yang mendahului individu. Masyarakat adalah sekelompok manusia yang membentuk sebuah sistem semi tertutup (atau semi terbuka), di mana sebagian besar interaksi adalah antara individu-individu yang berada dalam kelompok tersebut. Sebuah masyarakat adalah suatu jaringan hubungan-hubungan antar entitas-entitas yaitu sebuah komunitas yang interdependen (saling tergantung satu sama lain). Pembentukan komunitas ini merupakan proses yang dinamis karena anggota komunitas dapat berubah dan membentuk sebuah komunitas baru. Keberadaan komunitas ini yang kemudian membentuk sebuah ruang sosial atau social space. 
Ruang sosial atau social space adalah ruang, baik yang berbentuk fisik maupun non-fisik yang kegiatan utamanya adalah bersosialisasi. Ruang sosial merupakan pusat kehidupan masyarakat atau komunitas untuk berkomunikasi, berdiskusi, bertukar pikiran, belajar hingga bermain untuk lepas dari kegiatan sehari-hari mereka. Dari ruang sosial ini maka terbentuk sebuah istilah third place yang menggambarkan sebuah tempat yang mendorong adanya interaksi sosial diluar kegiatan sehari-hari.

Third place atau lingkungan ketiga merupakan sebuah lingkungan sosial yang terpisah dari dua lingkungan biasanya, yaitu: rumah (lingkungan pertama) dan tempat bekerja (lingkungan kedua). Oldenburg dalam bukunya The Great Good Place menjelaskan bahwa third place merupakan kehidupan komunitas dan memfasilitasi serta mendorong interaksi yang lebih luas dan kreatif. Third place menjadi sebuah tempat dimana orang bisa bersantai dan berjumpa dengan orang baru.

Third place dapat diartikan juga sebagai living room of society adalah sebuah tempat yang dapat menghidupkan kembali sebuah komunitas dan juga menjadi sharing place/social place. Tempat ini merupakan sebuah dialog antara privat dan publik.

\section{Masyarakat Individualis}

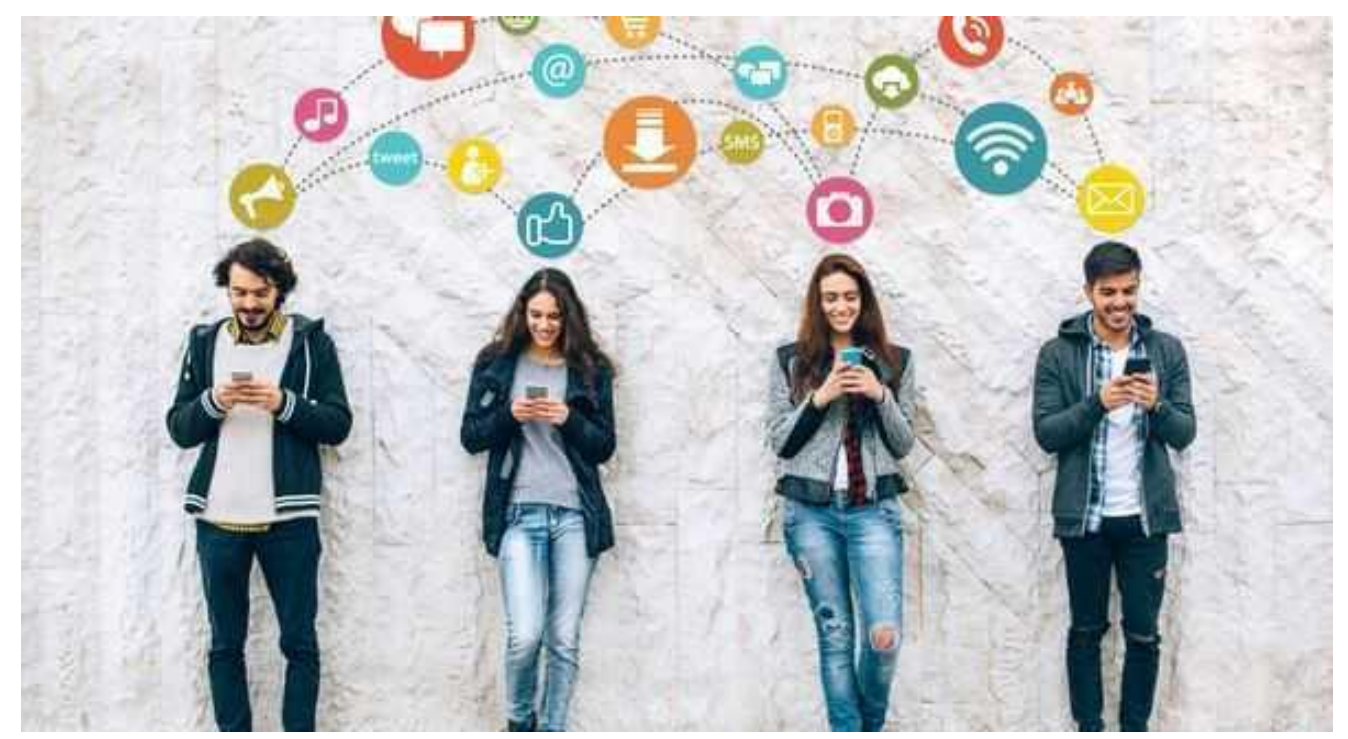

Gambar 1. Manusia mulai beralih kepada teknologi untuk berkomunikasi sehingga rasa individualis mulai muncul

Sumber: Kompasiana.com

"Individualis adalah sebuah paham yang menganggap diri sendiri (kepribadian) lebih penting daripada orang lain"- KBBI.

Hal ini umumnya terjadi pada masyarakat yang berada diperkotaan, khususnya yang tinggal di perumahan menengah keatas. Sifat ini menjadikan individu kurang bermasyarakat sehingga kejadian yang terjadi di lingkungan mereka dianggap tidak penting. Karena sifat ini, masyarakat cenderung cuek dan tidak peduli terhadap sekitarnya bahkan saat ini beberapa orang tidak mengenali tetangganya sendiri.

Individualis yang terjadi ditengah masyarakat dapat memberikan dampak negatif. Individualis tidak hanya terjadi didalam masyarakat dalam skala yang besar tetapi dalam keluarga yang berskala kecil, sehingga diperlukan adanya sebuah pemersatu yang dapat menyatukan manusia dengan manusia lainnya salah satunya melalui hobi atau kegemaran yang sama dan dapat melalui media hewan peliharaan. 


\section{Hubungan antara Manusia dan Hewan Peliharaan}

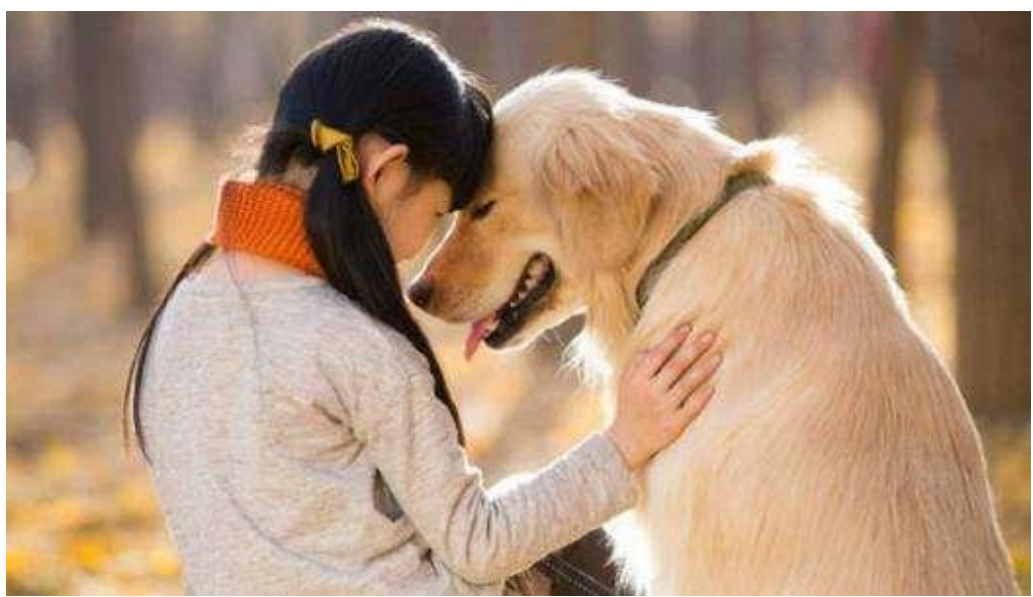

Gambar 2. Kedekatan Hubungan antara Hewan Peliharaan dengan Manusia Sumber: Arenahewan.com

Kehidupan manusia dan hewan selalu terjalin di sepanjang sejarah manusia. Manusia sebagai makhluk sosial tidak hanya berelasi dengan manusia lainnya, tetapi manusia juga mampu membangun hubungan relasi dengan hewan lainnya.

Kedekatan antara manusia dan hewan disebut dengan sebuah istilah Pet Attachment atau kelekatan dengan hewan peliharaan. Teori Pet Attachment didasari langsung dari teori Adult Attachment pada manusia yang dikemukakan oleh Bowlby. Bowlby mengartikan Attachment adalah ikatan emosional yang berlangsung antara individu dengan figur kelekatannya. Figur kelekatan ini dapat berupa individu lain ataupun figur lain seperti pada teori Pet Attachment adalah hewan peliharaan.

Attachment bonds dengan hewan dapat diwujudkan karena hewan adalah obyek attachment yang natural, mereka selalu ada disaat kita membutuhkan, aktif, lincah dan penyayang (Levinson, 1969). Hubungan timbal-balik yang terjadi oleh pemilik dan hewan peliharaan adalah hubungan yang saling melindungi dan mengasihi serta memberikan dukungan yang positif secara emosional. Hubungan antara hewan peliharaan dan pemiliknya merupakan suatu pola hubungan yang unik dan sederhana. Hubungan manusia dengan hewan peliharaannya dikategorikan sebagai stabilitas, konsistensi, kelembutan, kehangatan, kesetiaan, otentitas dan tidak ada penghakiman dan kompetisi.

Banyak efek positif yang didapatkan manusia dari aktivitas memelihara hewan. Dengan memelihara hewan peliharaan, seseorang mendapatkan tiga manfaat, yaitu:

- Membantu untuk memulihkan kesehatan dengan cara menerapkan gaya hidup sehat, seperti mengajak jalan- jalan dan bermain hewan peliharaanya;

- Membantu mengatasi stress dengan menganggap hewan sebagai hiburan dan teman bermain;

- Bersosialisasi dengan lingkungan dan orang-orang baru seperti saat membawa hewan peliharaan berjalan- jalan.

Selain itu, menurut McConnell dalam jurnalnya yang berjudul Friends With Benefits: On the Positive Consequences of Pet Ownership disebutkan bahwa hewan peliharaan dapat menjadi social support yang dapat meningkatkan kesehatan mental seseorang disaat dukungan dari sesama manusia berkurang.

Berdasarkan dari hasil wawancara yang saya lakukan dengan beberapa pemilik hewan peliharaan berupa anjing, mereka merasakan perubahan hidup kearah yang lebih positif ketika mereka memelihara anjing, seperti; mendapatkan teman baru, tidak merasa kesepian, dan memiliki rasa tanggung jawab yang lebih besar karena memelihara anjing memerlukan 
ketekunan dalam hal menyayangi dan merawat secara terus-menerus serta biaya yang dikeluarkan juga tidak sedikit. Bagi mereka, anjing sudah seperti keluarga bahkan anak atau adik mereka sendiri.

Sedangkan, dari sisi hewan peliharaan, ketika dirawat oleh manusia mereka mampu memenuhi kriteria kesejahteraan hewan. Kesejahteraan hewan adalah suatu kondisi yang diterima oleh hewan untuk hidup dengan baik atau sejahtera. Hewan dikatakan sejahtera jika hewan tersebut sehat, nyaman, cukup gizi, aman, dapat menampilkan perilaku bawaan, dan tidak menderita akibat rasa sakit, ketakutan dan kesusahan. Upaya menyejahterakan hewan yang baik juga ditunjukkan dengan adanya cara dari pemilik untuk melakukan pencegahan penyakit dan pengobatan terhadap hewannya, menyediakan kandang yang baik, memberikan makanan yang kecukupan gizi, dan penanganan yang manusiawi. Sedangkan bagi hewan, tidak ada hal lain yang diharapkan dalam hidupnya selain kesejahteraan itu sendiri.

Menurut Duncan dalam buku Understanding Animal Welfare. In: Animal Welfare ada tiga pandangan yang berbeda tentang kesejahteraan hewan. Ketiga pandangan tersebut adalah:

- Fungsi biologis hewan yang baik, ditandai dengan tingginya tingkat kesehatan, pertumbuhan, dan efisiensi produksi;

- Perasaan dan emosi yang baik ditandai dengan terhindar dari rasa nyeri dan penderitaan sehingga diusahakan hewan selalu menikmati kesenangan dan kehidupan normal;

- Pendekatan perilaku alami yang diperlihatkan bahwa hewan harus bebas dari kendala/kesusahan dan memperlihatkan pola-pola perilaku normal mereka.

Untuk memenuhi ketiga pandangan tersebut, maka saat ini mulai muncul beberapa tempat ramah hewan peliharaan seperti pet park, pet café dan lainnya. Meskipun demikian, ada beberapa kendala ketika hewan peliharaan dibawa ke tempat-tempat tersebut karena memiliki beberapa peraturan yang membuat hewan peliharaan merasa tidak bebas sehingga kesejahteraannya terganggu.

\section{METODE}

Metode yang digunakan adalah metode pembahasan secara deskriptif dengan mengidentifikasi data-data dan teori terkait yang bersifat kualitatif dan kuantitatif yang kemudian dianalisa untuk memperoleh program dasar dengan peluang kombinasi dari program dasar tersebut.

Pengumpulan data dilakukan dengan cara:

a. Studi literatur terkait teori, data, penelaahan, dan sejarah.

b. Melakukan survei dan observasi lapangan melalui penelitian dan pengamatan secara langsung terhadap objek

c. Studi preseden, dengan membedah rancangan-rancangan yang telah terbangun yang memiliki kemiripan program pada proyek yang diajukan

\section{DISKUSI DAN HASIL} Ide Perencanaan

Kurangnya ruang sosial bagi masyarakat, menyebabkan masyarakat mulai membuat ruangruang sosial mereka sendiri seperti dipinggir jalan, depan rumah hingga bermain ditengah gang jalan. Hal ini tentu cukup membahayakan bagi masyarakat dan pengguna jalan. Selain itu, dikarenakan ruang sosial yang kurang, masyarakat sekarang cenderung menutup diri sehingga menjadi sebuah masyarakat yang individualis. Oleh sebab itu, proyek ini direncanakan dapat menjadi sebuah ruang sosial atau thirdplace bagi masyarakat sekitar dengan fungsi utama berupa hiburan dan sarana komersil yang dapat menjadi keuntungan proyek.

Tujuan utama dari proyek adalah menjadi sebuah ruang sosial bagi masyarakat, mempersatukan masyarakat dari segala usia hingga golongan. Thirdplace sebagai sebuah 
perantara, sebuah lingkungan sosial yang dapat mengembalikan makna dari sebuah sosialisasi dan komunikasi.

Third Place merupakan sebuah lingkungan sosial yang memiliki ketertarikan yang sama.

Sebuah lingkungan sosial yang mampu membuat rasa aman, nyaman, setara dan menjadi sebuah satu kesatuan komunitas.

Konsep utama yang diambil dalam merancang adalah mengenai persamaan (similarity dan equality) yang bertujuan sebagai tempat untuk menyatukan serta menyetarakan antar manusia, baik dengan sesama maupun hewan dan alam.

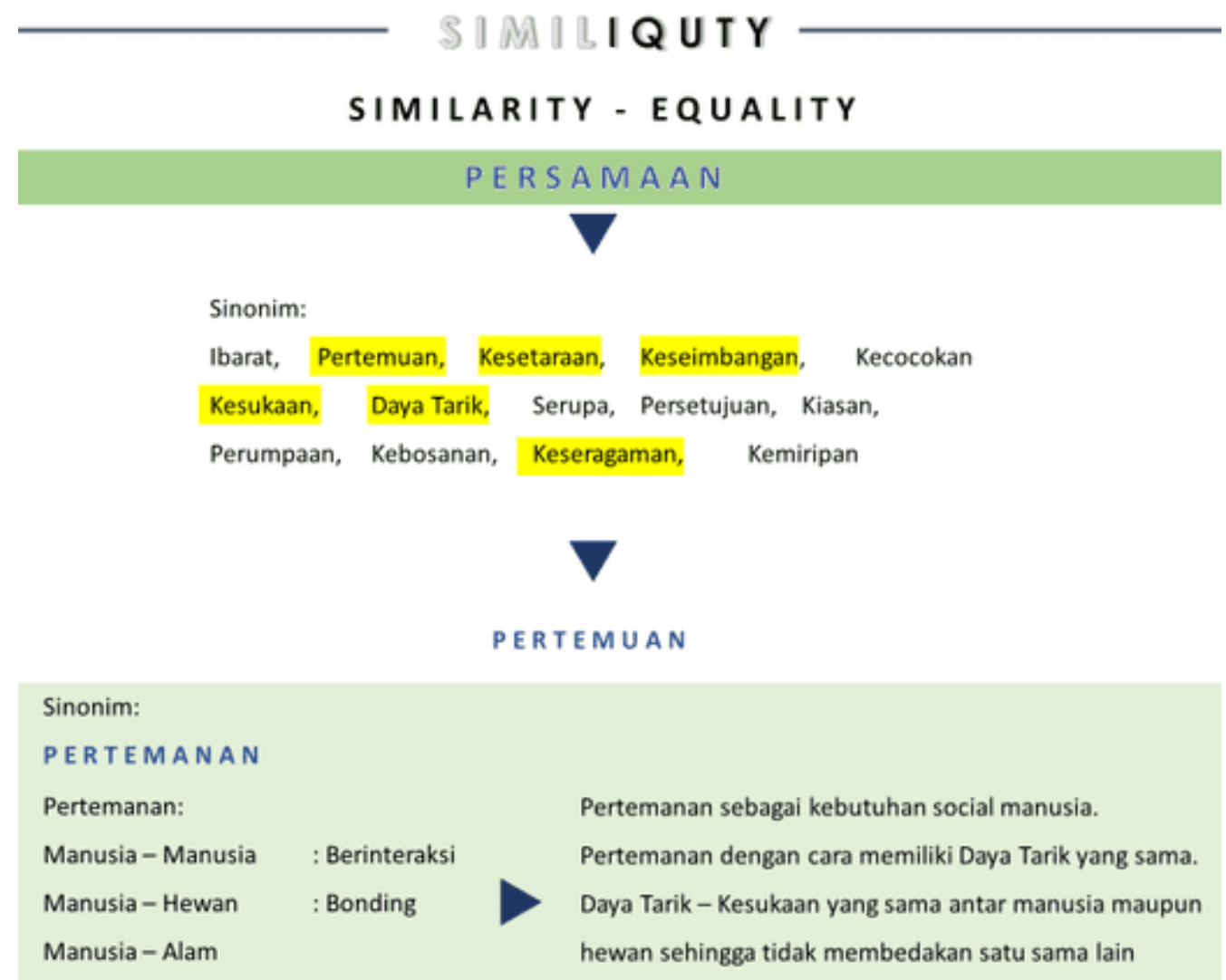

Gambar 3. Skema Konsep Utama: Similarity - Equality

Sumber: olahan penulis, 2019

Setiap masyarakat memiliki ketertarikannya tersendiri terhadap sesuatu. Ketika memiliki sebuah ketertarikan yang sama, orang akan cenderung untuk membaur bersama. Hal tersebut yang akan dicapai oleh proyek ini salah satunya dengan ketertarikan kepada hewan peliharaan domestik.

Tahapan perancangan proyek dengan konsep similarity - equality diterapkan sebagai berikut:

- Perancangan proyek didasari oleh 8 kriteria third place Ray Oldenburg, dengan menitik beratkan salah satu kriteria yaitu, a home far away from home, diibaratkan sebagai sebuah rumah yang akan selalu ada ketika kita membutuhkannya;

- Perancangan didasarkan pada axis melintang tapak dan memiliki area terbuka utama kearah boulevard sebagai sebuah taman open space dan area penerimaan pedestrian;

- Proyek memiliki bukaan berupa taman yang berada didepan dan belakang sebagai tempat terbuka khususnya bagi hewan-hewan peliharaan;

- Proyek memiliki bentuk simetris, dengan fasad menyerupai rumah sehingga memberikan kesan aman dan nyaman. Sebuah tempat yang digunakan secara bersama-sama untuk meningkatkan hubungan ikatan baik manusia dengan manusia, dengan hewan dan juga alam. 
Berdasarkan analisa tapak dan studi kasus terkait, tapak akan terbagi menjadi 3 zona besar, yaitu:

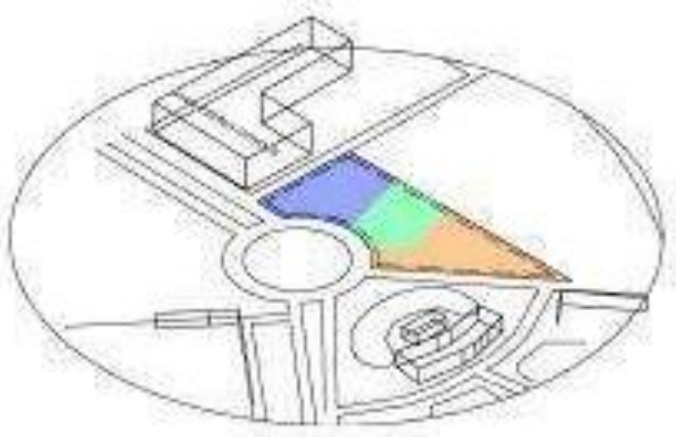

\author{
Human to Human Zone \\ - Human and Pets Zone \\ - The Bridge atau ruang perantara
}

Gambar 4. Pembagian Zoning Tapak secara Horizontal Sumber: olahan penulis, 2019

Proyek tidak akan memiliki lahan parkir, karena sasaran dan target merupakan masyarakat yang terdapat disekitar tapak, yaitu yang berasal dari beberapa perumahan disekitar tapak. Selain itu, sesuai dengan kriteria third place oleh Ray Oldenburg yaitu Leveler dimana semua orang sama sehingga status ekonomi dan jabatan seseorang tidak akan dipandang pada proyek ini.

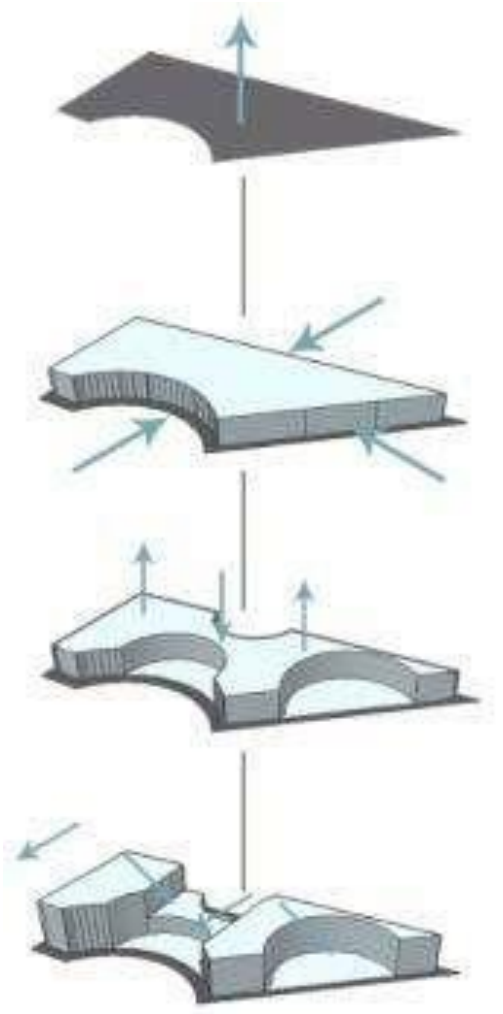

Gambar 5. Design Scheme

Sumber: olahan penulis, 2019

Proses pembentukan massa, diambil dari garis-garis pada tapak sehingga memberikan bentuk yang unik, karena berada di Boulevard. Sehingga entrance utama akan berada ditengah, berhadapan dengan boulevard, untuk pedestrian. Untuk kendaraan dapat men-drop off pada entrance yang berada disamping proyek. 
Setelah melalui proses analisis aktivitas, zoning tapak, konsep perancangan hingga gubahan massa di atas, maka dapat disimpulkan kebutuhan sebagai berikut:

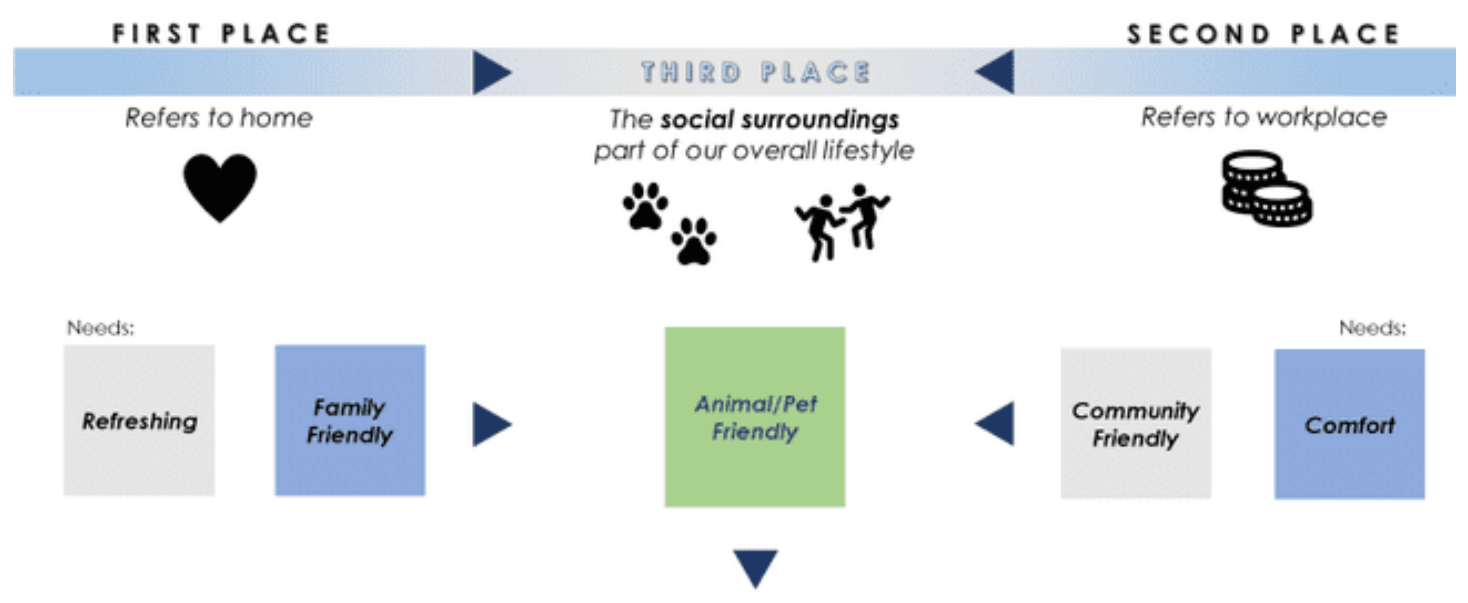

Pertemuan antara manusia dan hewan, menjadi sebuah daya tarik tersendiri terhadap thirdplace yang akan dirancang.

Gambar 6. Proses Pembentukan Program Bangunan Sumber: olahan penulis, 2019

Dari kebutuhan-kebutuhan pada first place, second place dan third place maka ditemukan beberapa kata kunci yang mewakili ketiga tempat tersebut. Animal Friendly atau Pet Friendly digunakan sebagai daya tarik terhadap third place yang dirancang. Sehingga, muncul beberapa program yang mewakili setiap kata kunci yaitu:
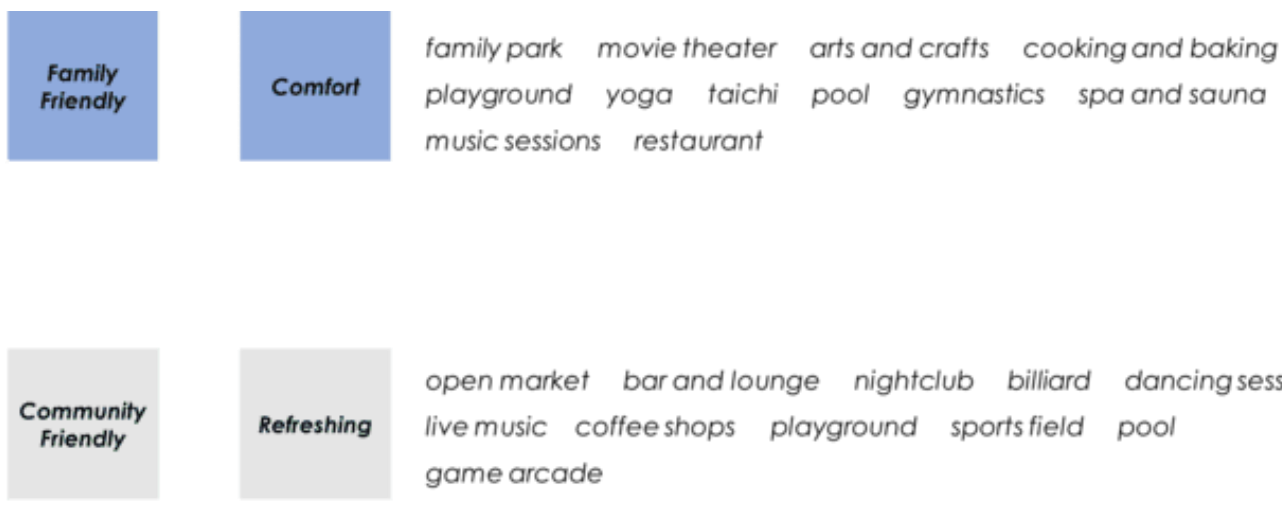

openmarket barandlounge nightclub billiard dancingsessions livemusic coffeeshops playground sportsfield pool game arcade

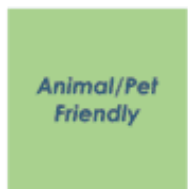

petpark petcare petsaloon petgrooming petshop petcafe adoptioncenter animalhealthcare animalschool \& training pool

Gambar 7. Rencana Program Bangunan Sumber: olahan penulis, 2019 
Program-program tersebut kemudian disortir kembali sehingga menghasilkan programatik akhir yaitu:

\section{Manusia x Hewan}

Program ini lebih mengarah pada kata kunci community friendly dan refreshing dimana program ini dirancang semenarik mungkin sehingga dapat menciptakan sebuah komunitas pencinta hewan dan sebagai sarana pembelajaran untuk mengenal hewan peliharaan berupa anjing, kucing dan kelinci lebih lanjut.

Program ini terdiri dari:

- Interactive Dog park: Taman interaktif untuk anjing, didesain untuk pencinta anjing, sebagai tempat berkumpul komunitas hewan-hewan.

- Interactive Rabbit Park: Taman interaktif Bersama kelinci, didesain khususnya untuk anak-anak agar dapat mengenal hewan sejak dini sehingga memiliki rasa sayang terhadap hewan.

- Cat Space Café: Café yang didesain ramah hewan peliharaan, khususnya kucing. Café ini memberikan ruang bergerak bebas untuk kucing bergerak sesuai dengan naluri dan tabiat aslinya.

- Pet Leisure: Program yang didesain untuk menunjang kesejahteraan hewan peliharaan berupa pet spa, grooming dan salon.

\section{Manusia x Manusia}

Program ini mengarah pada kata kunci family friendly dan comforting dengan tujuan utama membangun relasi yang lebih baik dalam keluarga dan memberikan kenyamanan dengan memiliki daya tarik atau hobi yang sama dengan orang lain.

Program ini terdiri dari:

- Street Market: Sebuah pasar yang menjual berbagai macam barang, mulai dari makanan hingga bahan-bahan untuk workshop.

- Open Lounge: Tempat berkumpul, sebagai titik temu orang-orang untuk bercengkrama sambal melihat kearah taman.

- Workshop: Sebuah tempat untuk menyalurkan kreasi, dengan tujuan utama memperkuat hubungan antara orang tua dan anak mereka. Workshop dilakukan secara terjadwal tanpa biaya dan dengan biaya apabila ingin melanjutkan kelas lanjutan. Kelas workshop yang dibuka adalah cooking and baking serta arts and crafts.

- Game Arcade: Sebuah tempat sebagai penyaluran hobi khususnya bagi anak-anak muda sehingga pada Game Arcade disediakan beberapa permainan seperti; karaoke box, table soccer, billiard, darts hingga outdoor playground. Disisi lain, terdapat juga e-sports game center sebagai penyaluran hobi anak muda masa kini. 


\section{P R O R A A T I K}

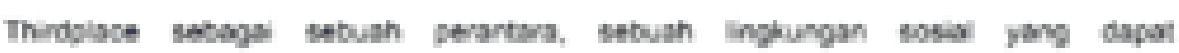

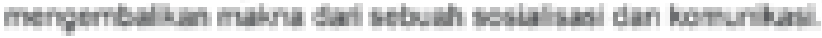

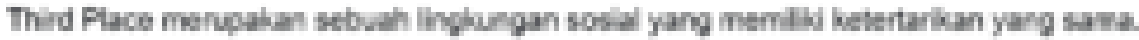

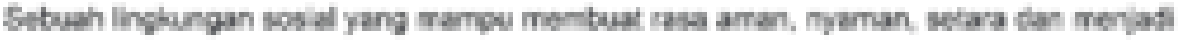

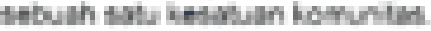

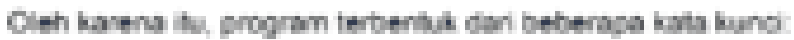
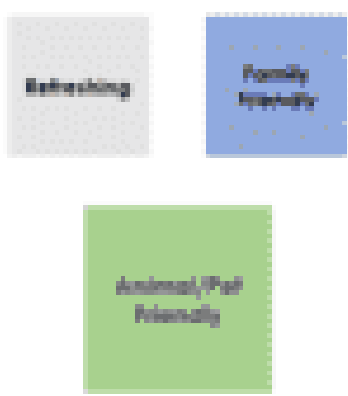

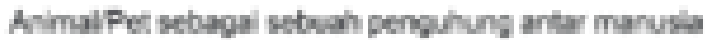

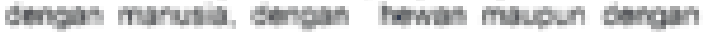
alyt

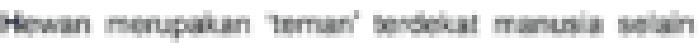
manusa liming

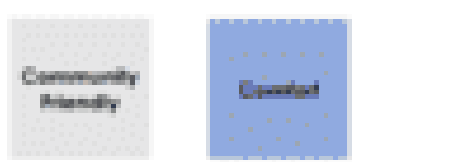

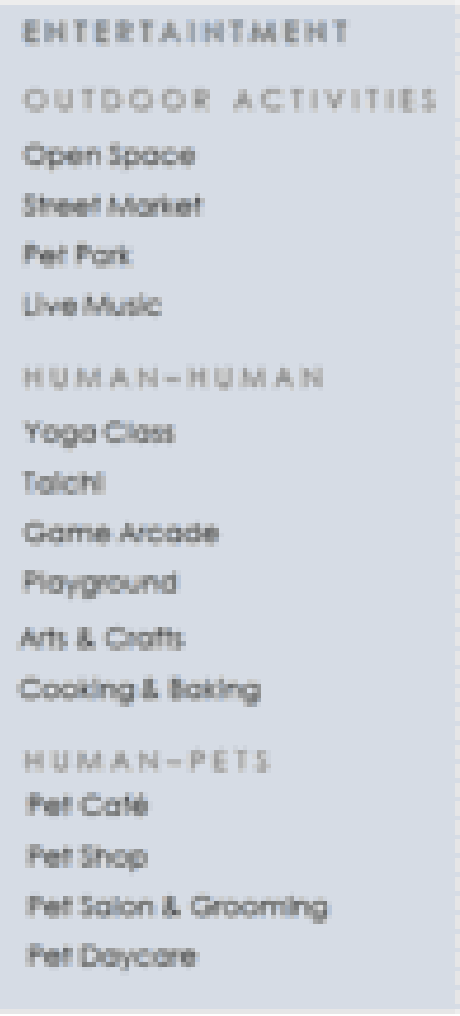

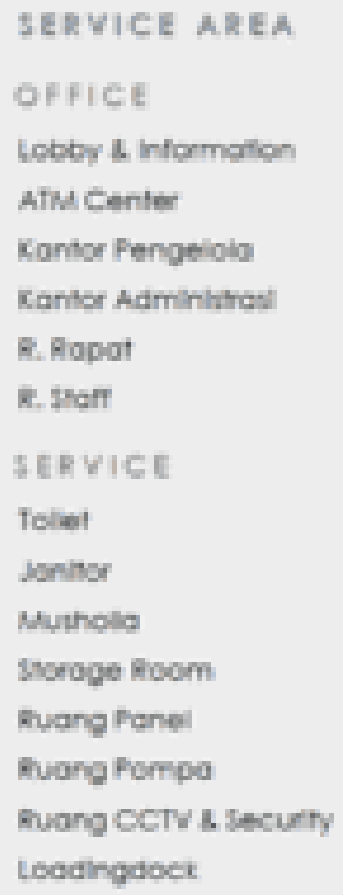

Gambar 8. Programatik Bangunan

Sumber: olahan penulis, 2019 


\section{Kawasan dan Lokasi}

Dari program-program tersebut, maka muncul beberapa kriteria kawasan sebagai berikut:

a. Kawasan memiliki tingkat individualis yang tinggi, berada disekitar perumahan menegah keatas

b. Kawasan memiliki tingkat kepadatan penduduk yang tinggi

c. Kawasan memiliki kesadaran akan kesejahteraan hewan peliharaan yang rendah

d. Kawasan belum memiliki tempat sebagai ruang sosialisasi terutama sosialisasi yang ramah hewan.

Tabel 1. Tabel perbandingan antara jumlah penduduk di Jakarta dengan kepemilikan hewan peliharaan dan tingkat kepadatan penduduk

\begin{tabular}{lllllll}
\hline No & Wilayah & $\begin{array}{l}\text { Jakarta } \\
\text { Utara }\end{array}$ & $\begin{array}{l}\text { Jakarta } \\
\text { Selatan }\end{array}$ & $\begin{array}{l}\text { Jakarta } \\
\text { Barat }\end{array}$ & $\begin{array}{l}\text { Jakarta } \\
\text { Timur }\end{array}$ & $\begin{array}{l}\text { Jakarta } \\
\text { Pusat }\end{array}$ \\
\hline 1 & Jumlah Penduduk & 1,78 juta & 2,23 juta & 2,53 juta & 2,89 juta & 921 ribu \\
\hline 2 & $\begin{array}{l}\text { Tingkat Kepadatan } \\
\text { Penduduk }\end{array}$ & 11.93 & 15.472 & 19.017 & 15.124 & 18.993 \\
\hline 3 & Persebaran Pemilik Hewan & $7.1 \%$ & $16.2 \%$ & $20.2 \%$ & $15.2 \%$ & $8.2 \%$ \\
\hline
\end{tabular}

Sumber: Badan Pusat Statistik Provinsi DKI Jakarta dan Ypsj.or.id

Dari data tersebut, dapat disimpulkan bahwa kawasan Jakarta Barat memiliki persebaran pemilik hewan peliharaan yang paling tinggi dengan tingkat kepadatan penduduk yang tinggi.

Tabel 2. Tabel perbandingan antara jumlah penduduk Jakarta Barat dengan kepemilikan hewan peliharaan

\begin{tabular}{|c|c|c|c|c|c|c|c|c|}
\hline Kecamatan & $\begin{array}{c}\text { Grogol } \\
\text { Petamburan }\end{array}$ & Cengkareng & Kalideres & Kembangan & Palmerah & Taman sari & Tambora & $\begin{array}{c}\text { Kebon } \\
\text { Jeruk }\end{array}$ \\
\hline $\begin{array}{c}\text { Jumlah } \\
\text { Penduduk }\end{array}$ & 224.040 & 512.998 & 392.678 & 269.756 & 215.619 & 124.656 & 260.384 & 326.590 \\
\hline $\begin{array}{c}\text { Kepemilikan } \\
\text { hewan } \\
\text { peliharaan }\end{array}$ & $36 \%$ & $20 \%$ & $17 \%$ & $14 \%$ & $2 \%$ & $4 \%$ & $3 \%$ & $4 \%$ \\
\hline $\begin{array}{c}\text { Fungsi sejenis } \\
\text { Program } \\
\text { Utama }\end{array}$ & $\begin{array}{c}\text { Central Park } \\
\text { Mall }\end{array}$ & - & Pet café & $\begin{array}{c}\text { Barkber } \\
\text { shop }\end{array}$ & - & - & - & - \\
\hline
\end{tabular}

Sumber: Badan Pusat Statistik Kota Administrasi Jakarta Barat

Dari tabel tersebut,Kawasan Cengkareng memiliki jumlah penduduk paling padat dengan kepemilikian hewan peliharaan sekitar $20 \%$. Sehingga dapat dibangun sebuah thirdplace dengan media dayatarik hewan peliharaan bagi masyarakat sekitarnya.

Dari kawasan Cengkareng, dapat dimunculkan beberapa kriteria untuk tapak, yaitu:

a. Tapak berada pada zonasi yang diperuntukkan untuk Zona Perkantoran, Perdagangan, dan Jasa atau Zona Pelayanan Umum dan Sosial.

b. Tapak berada ditengah perumahan menegah ke-atas dengan jumlah kepadatan penduduk yang tinggi. 


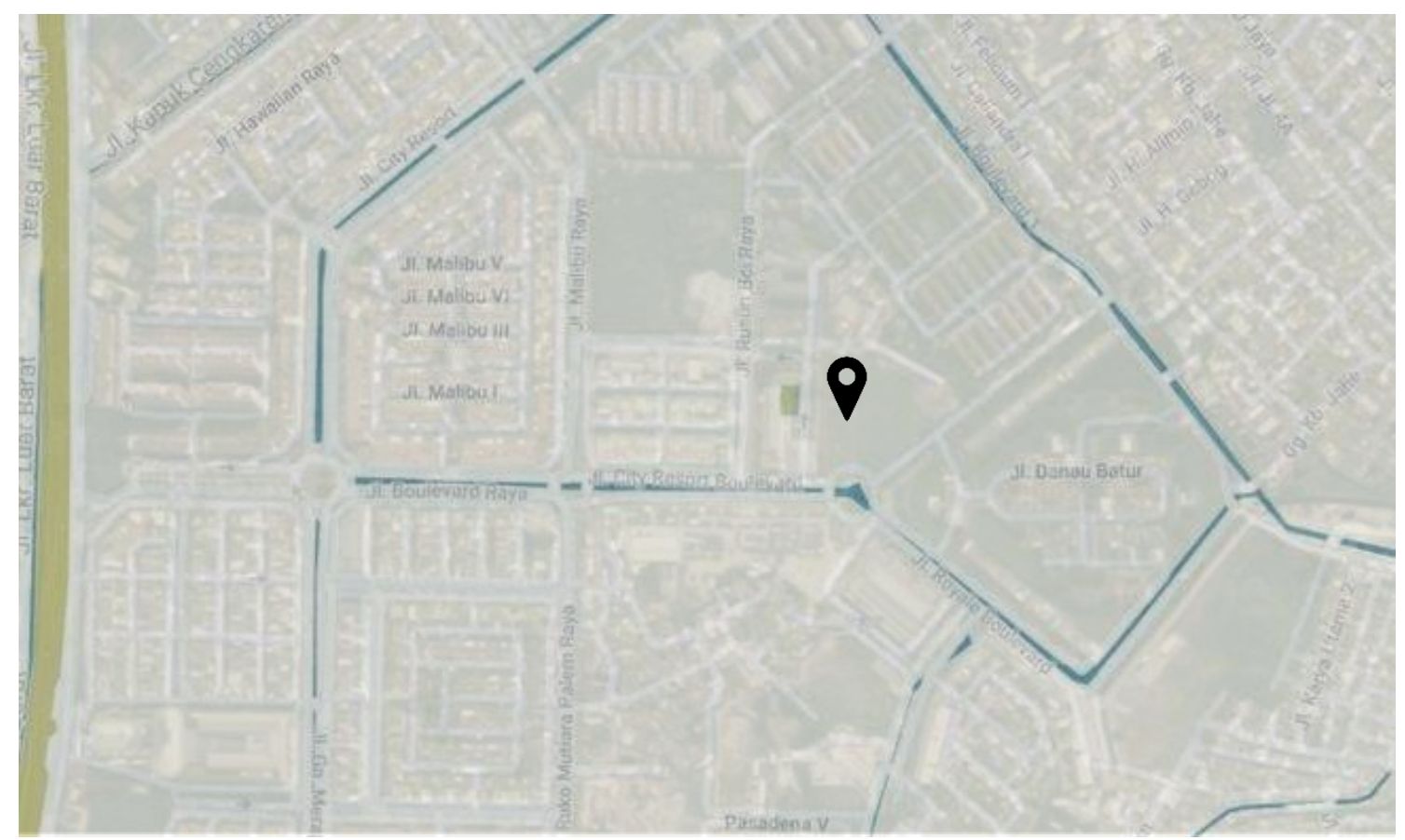

Gambar 9. Lokasi Tapak Terpilih

Sumber: maps.google dan olahan penulis, 2019

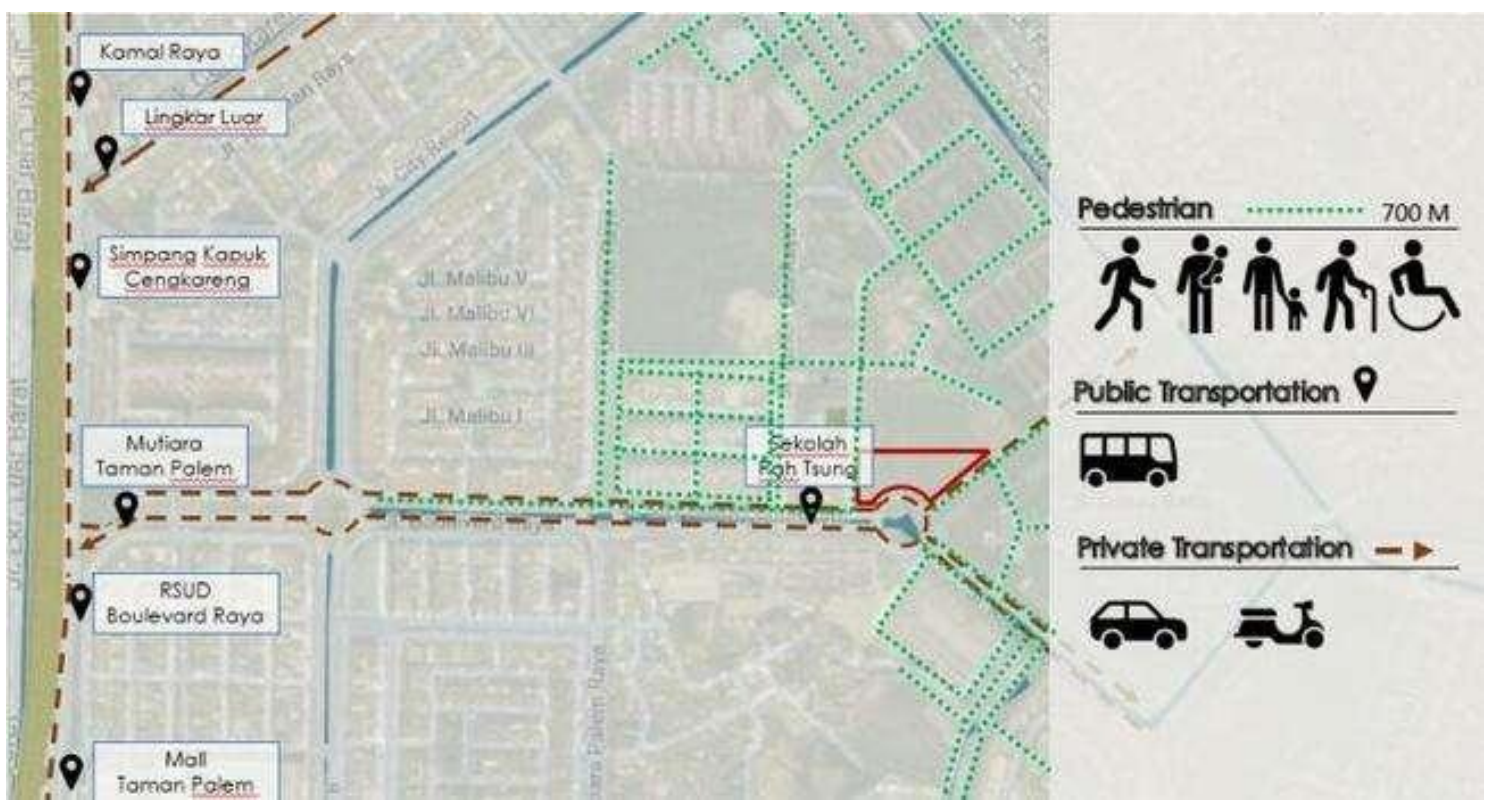

Gambar 10. Aksesibilitas menuju Tapak

Sumber: maps.google dan olahan penulis, 2019

Akses menuju tapak dapat dicapai melalui baik transportasi umum (bus transjakarta) dan transportasi pribadi serta berjalan kaki.

Halte tersedkat dengan tapak adalah halte bus pengumpan Trans Jakarta Sekolah Pah Tsung dengan rute:

- Rute 3 E (Sentraland - Puri Kembangan - Puri Kembangan)

- Angkot M 13 (Kalideres - Kota)

- Kereta Tanggerang Line 


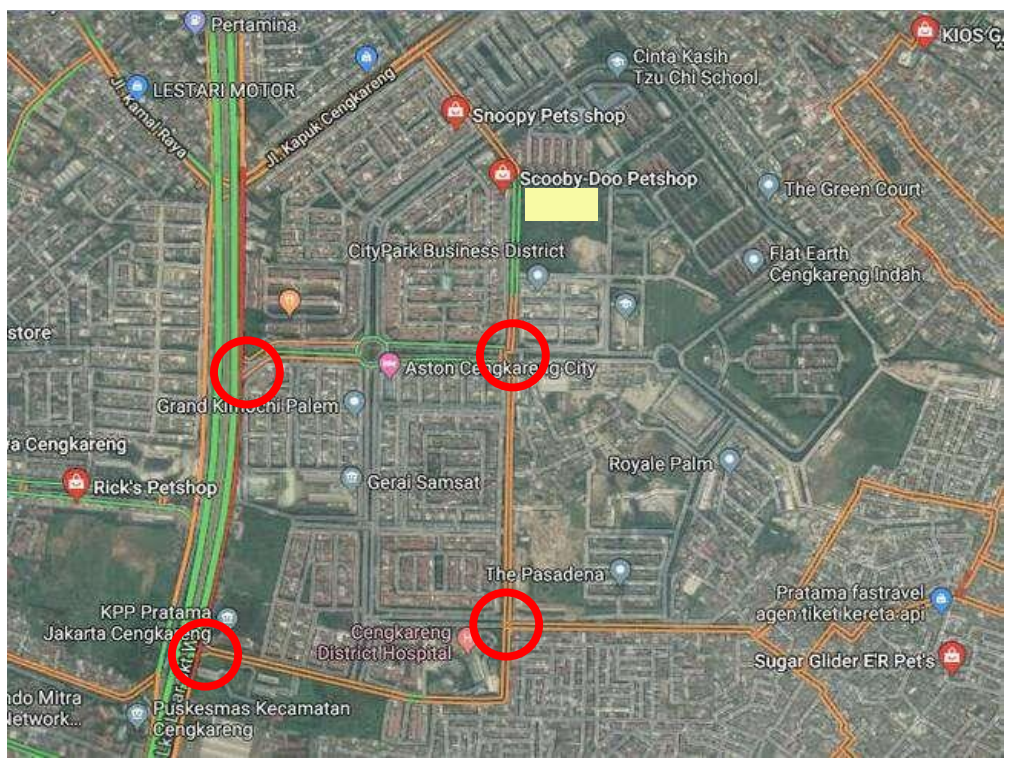

Gambar 11. Titik Kemacetan Akses Tapak

Sumber: maps.google dan olahan penulis, 2019

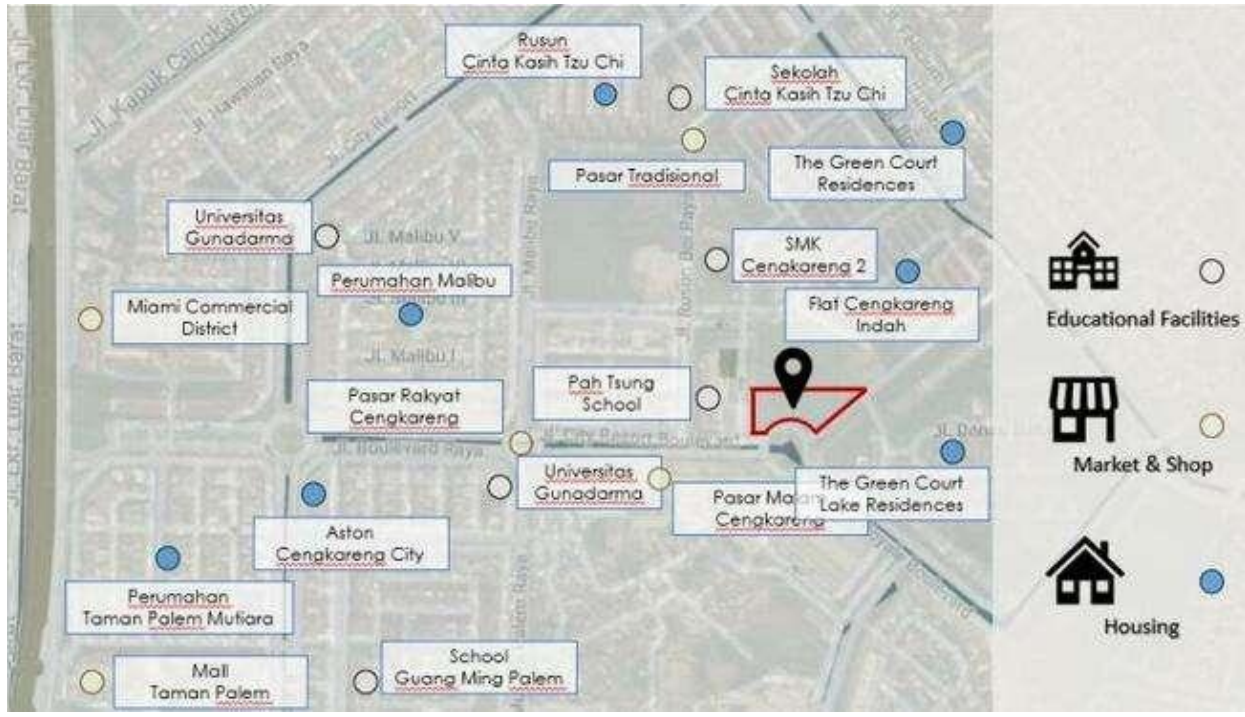

Gambar 12. Fasilitas Sekitar Tapak

Sumber: maps.google dan olahan penulis, 2019

\section{Konsep dan Strategi Desain}

Konsep diambil berdasar pada kebutuhan masyarakat akan sebuah ruang sosial atau third place. Masyarakat menjadi pribadi yang individualis karena beberapa faktor dan salah satunya adalah kurangnya ruang untuk bersosialisasi sehingga mereka menutup diri. Oleh karena itu, ruang sosial atau third place dibutuhkan untuk menyatukan dan menyetarakan masyarakat. Menyatukan dan menyetarakan ini dilakukan dengan mempelajari ketertarikan yang sama pada masyarakat. Salah satunya adalah ketertarikan terhadap hewan peliharaan domestik.

Desain dibuat berdasarkan kebutuhan masyarakat sekitar mengenai ruang sosial. Berangkat dengan kriteria thirdplace dari Ray Oldenburg, salah satunya adalah 'home far away from home' maka desain lebih menunjukan sebuah kenyamanan rumah sebagai tempat tinggal bersama. Desain ini dibuat agar konsep kenyamanan rumah akan semakin terlihat dan dapat menjadi sebuah wadah yang dapat digunakan secara bersama-sama untuk meningkatkan hubungan ikatan antara sesama manusia maupun dengan hewan dan juga alam. 


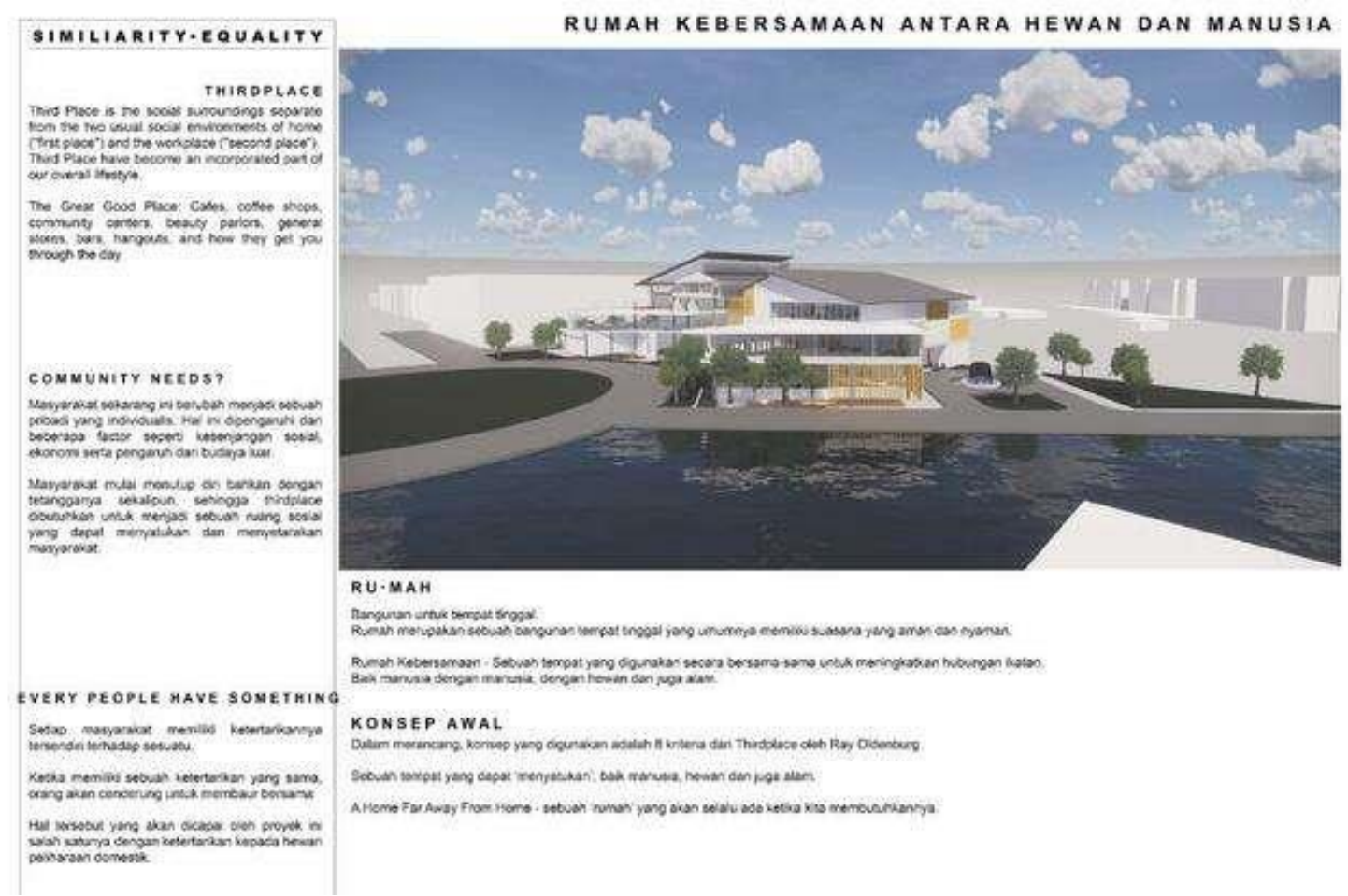

Gambar 13. Konsep dan Strategi Desain Bangunan Sumber: olahan penulis, 2019

\section{Kesimpulan dan Saran}

Third place atau lingkungan ketiga merupakan sebuah lingkungan sosial, sebuah komunitas sebagai tempat untuk bersantai dan bersosialisasi dengan orang lain. Third place setiap orang memiliki ciri khas yang merupakan sebuah identitas atau lokalitas dari masyarakat sekitar.

Rumah Kebersamaan antara Manusia dan Hewan akan terletak di Cengkareng, tepatnya di Jl. Boulevard Raya, karena pada tapak tersebut dikelilingi oleh 6 perumahan dan 1 fasilitas tempat tinggal. Tingkat individualis pada area tersebut cukup terlihat sehingga fenomena individualis diangkat dan berharap akan dapat mengurangi tingkat individualis pada area tersebut.

Rumah Kebersamaan antara Manusia dan Hewan merupakan sebuah third place dengan mengangkat sebuah fenomena individualis yang terjadi di perumahan, khususnya tingkat menengah keatas, sehingga diharapkan dengan adanya proyek ini, tingkat interaksi dan hubungan relasi antar keluarga maupun antar sesama tetangga dengan sebuah pengikat berupa hewan peliharaan dapat lebih meningkat. Tujuan utama dari proyek adalah menjadi sebuah ruang sosial bagi masyarakat, mempersatukan masyarakat dari segala usia hingga golongan.

Program akan dirancang sesuai dengan kebutuhan manusia yaitu sebuah tempat untuk berkumpul, menjalin hubungan dan refreshing bersama hewan peliharaannya. Selain itu, program akan menyesuaikan dengan kebutuhan masyarakat sekitarnya dengan membagi zoning pada setiap lantainya yaitu; manusia dan hewan, manusia dan manusia, sehingga tercipta adanya hierarki antar ruang yang terbentuk.

Sehingga, berdasarkan kebutuhan tersebut, proyek akan memiliki program utama yaitu Entertainment dengan fungsi berupa Community Pet Space Park dan Game Arcade dan Commercial dengan fungsi Street Market dan Workshop.

Proyek ini juga bertujuan untuk menjadi sebuah tempat komunitas bagi pencinta hewanhewan untuk berkumpul, serta mampu berbagi pengalaman dan menjadi sarana Pendidikan bagi anak-anak untuk belajar mencintai alam dan hewan. 


\section{REFERENSI}

Aronson, E. (2011). The Social Animal. New York (US): Worth Publishers.

Baron RA, Byne D. (2005). Psikologi Sosial Edisi Kesepuluh. Jakarta (ID) : Erlangga.

Bowlby, J. (1983). Attachment: Second Edition. New York (US): Ingram Publisher Services

Brown, S.,E., \& Katcher, A. H. (2001). Pet Attachment and Dissociation. Society and Animals

Compton, W.C. (2005). An Introduction Positive Psychology. Belmont (US): Wadswort.

Duncan IJH, Fraser D. (1997). Understanding Animal Welfare. In: Animal Welfare. United Kingdom (UK): CAB Imternasional, Wallingford

McConnell AR, Brown CM, Shoda TM, Styto LE, Martin CE. (2011). Friends with benefits: on the positive consequqnces of pet ownership. J. Personality and Social Psychology.

Oldenburg, R. (1999). The Great Good Place. US: Da Capo Press

Kbbi.web.id.Individualis.Diakses tanggal 12 Desember 2019, dari https://kbbi.web.id/individualis

Kompasiana.com. Gaya Hidup Individualis di Masyarakat. Diakses tanggal 12 Desember 2019, dari https://www.kompasiana.com/aningg/5816d811bc9373b90a56fbea/gaya-hidupindividualis-di-masyarakat

Kompasiana.com. Mewabahnya Sikap Individualis Pada Masyarakat Indonesia dan Mengatasinya. Diakses tanggal 12 Desember 2019, dari https://www.kompasiana.com/retnowitaningtyas/58164eed129773fd34bd5bfc/mewabahn ya-sikap-individualis-pada-masyarakat-indonesia-dan-mengatasinya

Simplypsychology.org. Attachment Theory. Diakses tanggal 27 Agustus 2019, dari https://www.simplypsychology.org/attachment.html

Study.com. Theories of Adult Development: Levinson, Vaillant \& Neugarten. Diakses tanggal 27 Agustus 2019 dari https://study.com/academy/lesson/theories-of-adult-developmentlevinson-vaillant-neugarten.html

Wikipedia.com. Individualis. Diakses tanggal 12 Desember 2019, dari https://id.wikipedia.org/wiki/Individualis 
